\title{
Majeed Syndrome
}

National Cancer Institute

\section{Source}

National Cancer Institute. Majeed Syndrome. NCI Thesaurus. Code C119058.

An autoinflammatory disease caused by mutations in the LPIN2 gene. It is characterized

by early-onset chronic recurrent multifocal osteomyelitis, cong enital dyserythropoietic anemia and inflammatory dermatosis. 